\title{
Influence of Age on Students' Alternative Conceptions of Scientific Phenomena
}

\author{
Theresa Ugonwa Okafor \\ Department Of Science Education, ChukwuemekaOdumegwuOjokwu University, PMB 02 ,Uli, Anambra State, \\ Nigeria.
}

\begin{abstract}
The study was designed to investigate the influence of age on students' alternative conceptions of scientific phenomena. The study employed an ex-post-facto design and was conducted in some sampled schools in Aguata education zone of Anambra State. The sample for this study comprised of five hundred and twenty two SS I students. The study was carried out in 8 secondary schools ( 4 boys and 4 girls). The schools were drawn through a stratified random sampling. In each school, intact class of SS I was used. Two research question and one hypothesis guided the study. An instrument known as Alternative Conception of Scientific Phenomena Test (ACSPT) was developed by the researcher and used for data collection. The research questions were answered using frequencies and percentages while the hypothesis was tested using cross tabulation with chi-square test of independence as the test statistic. It was revealed that age is not a significant factor in student's conception of motion. The reasons for the students' alternative conception of motion were centered on culture and practices prevailing in the environment. Based on the findings of the study, the researcher recommendation that alternative scientific conceptions based science instruction should be adopted in our school system; Ministry of Education and Professional Organizations like STAN should organize workshops, seminars and conferences for Physics teachers on the use of the scientific alternative conception based package and the use of conventional instructional approach should be de-emphasized in our school system since it encourages rote-learning. Physics teachers should employ the principles of the alternative conception of science to enhance knowledge acquisition among students.

Keywords: Influence of age, Alternative conceptions, Scientific phenomena

DOI: $10.7176 / \mathrm{JEP} / 10-9-22$

Publication date:March $31^{\text {st }} 2019$

\section{Introduction}

Science as pointed out by Abimbola, (2013) in Kharis, (2016) is a body of knowledge, a way of investigating natural phenomena and a way of thinking in an attempt to understand nature. The knowledge of science and its implication is very important in our world today. Science has made a lot of tremendous achievements which has helped mankind in remarkable ways. Science, especially physics, is important to mankind, not only because it helps to satisfy our curiosity, but also helps to channel our curious mind to discovering and creating things. Physics in particular, not only solves man's problems and attain to daily needs but also proffer solutions to seemly difficult situations such as curing health issues Kaharis, 2016. Exlina (2000), observed a similar thought in his work where he was of the opinion that Science (Physics) is important to the public because it addresses issues that are the concern of the populace.
\end{abstract}

Physics is the study of matter, energy, and the interaction between them. Physics according to Kaharis (2016), has broken the barrier of limitations in many fields, brought explanations to myths and mysterious happenings, removed the covering of superstitions from physics student's minds and unveiled the conceptual approach to life.

The past decade of research in science education has dealt with many researchers into children's ideas (Sadler, 2007). Sadler further observed that most students have ideas or understandings that are quite different from their teachers or scientists. Even when much effort has been made to explain physics concepts to students, the students still hold to those alternative conceptions.

Alternative conceptions according to Driver and Bell (2009) are the information taken by learner from environment in which they construct personal interpretation and meaning based on prior knowledge and experience. They stress that alternative conceptions involve the study of intuitive motions or informal knowledge held by students on 
scientific conceptions, which made learning meaningless. In view of this, Bruner (2010) said that meaningful learning depends on the learner's success in finding or creating connections between new information (Formal Knowledge) and pre-existing knowledge. According to Bruner, one way by which these connections are made is through the use of analogy. By analogy he means that in the learning process of scientific concepts a search for similarities between what is already known and the new or the alternative conception and the scientist's conception.

Alternative conceptions are therefore those ideas children hold about scientific concepts before coming to the classroom. Osborne \& Freyberg (2000) in consonance with Duckworth (2010), pointed out that a lot of papers have been published revealing students' conceptions in different domains, for instance, Eckstein \&Shemesh (1992) carried out an investigation on students' conception on "Projectile motion". They found out that a student held concept that ball falling from the edge of a table would fall straight down instead of exhibiting a motion path or trajectory path of a parabola. "These pre-conceptions will now form a base through which new information is processed and understood" (Anderson, 1990; 5) The alternative conception based technique if inculcated into curriculum, will enhance the students' active participation and better understanding in the actual teaching learning process of physics concepts such as "Motion".

The study of alternative conceptions of scientific conceptions will help the discrepant events that high light the difference between student's conceptions to be explained to students during teaching and learning process so as to stimulate them to relinquish their intuitive ideas in favour of Scientists science (Congrove and Osborne, 2005). This study will help the learning of science education in Nigeria in particular because the science teachers can now think of better methods of making the students construct meaningfully. Recently efforts are being made to investigate into alternative conceptions of children in science education, Bruner (1996) earlier noted that concepts constitute basic elements one should understand in other to teach or learn science. From Physiological perspective, Okafor (2008:143) states "concepts originate as a result of sensation which is the cerebral cortex of the brain where the image of the object which generated the stimulus is formed".

In an empirical study conducted by Eckstein and Shemesh (1989) on students' age and alternative conception, they showed that the ideas of children are not static and the transformations of ideas increase with age. However, two different studies were carried on a quantitative comparison between Piagetian stages of development and stages of conceptual development byShayer\&Wylam (1981). They investigated the percentages of children at the concrete (0-2 years), late concrete (2-4 years) and formal stages (4-8 Years) of Pigetian development using the mathematical model used by Eckstain and Schemesh to do the analysis. They calculated the half-lives, T1 for boys and T2 for girls. T1 for the transition from concrete to late concrete, and T2 from late concrete to formal. They found out that the half-live was found to be 2.5 years for boys and 7.8 years for girls. This situation coupled with poor formation of science concepts among students (Eze, 2014) and overall poor academic achievement of secondary students in science raise doubts in the efficacy of the existing instrumental approaches in science. In fact, the current approaches in science instruction in Nigeria have been criticized as hopeless and incapable of bridging the wide differences between the initial background of the learners and the new field of knowledge (Fafunwa, 1983).

The level of students' achievement and interest in science subject in general and physics in particular has not been as encouraging as expected for instance, the chief examiner's report of the West African Examination Council (WAEC, 2010) for both Senior School Certificate Examination (SSCE) May/June and November/December (GCE) 2010, respectively revealed that the weakness of students in science accrued from poor knowledge of basic scientific concepts and scientific terms, like in physics subject, the students' knowledge on motion as a concept is very poor.

The implication of this statement is that the conception of students' on motion as a basic scientific concept is very far from expected perhaps, the poor performance of students in physics subject with particular reference to motion as a concept could be arrested by exploring the influence of age in students alternative conception in motion. 
Research Questions:

c) What are the alternative conceptions held by students about "motion"

d) To what extent does age influence the alternative conceptions of students in motion?

Hypothesis

$\mathrm{HO}_{1}$ : Senior Secondary School students' alternative conceptions of “motion" are significantly independent of age.

\section{Methods}

Stratified random sampling technique was used in drawing the sample for the study. In stratified random sampling, the population is divided into certain characteristics of males and females or urban and rural and a proportionate random sample is then drawn from each identified characteristics called stratum.

For the purpose of this, the schools were stratified into boys and girls. In the zone there are 8 boys and 9 girls schools. Out of 8 boys' school, 4 schools were randomly sampled and for girls, 4 schools were also sampled and for girls, 4 schools were also sampled randomly this gave a total of 8 schools for the study. The entire SS1 students in the sampled schools formed the sample size. The total of boys was 204 and girls were 318 . The sum of boys and girls was 522 .

The instrument for data collection was Alternative Conception of Scientific Phenomena Test (ACSPT) which was developed by the researcher. It contained ten items designed to elicit and identify secondary school students' alternative conceptions as contained in the senior secondary physics curriculum:

- Types of motion

- Relative motion

- Causes of motion

- Types of forces

- Reducing friction

- Simple idea of circular motion.

The instrument consists of two sections 'A' and 'B'. Section A, was concerned with the background information relating to the respondents such as name of the school and age. Section B consists of 10 items on motion. Each item was followed by three options. Each option reflects (a) Western Scientific (WS) (b) Supernatural View (SW) (c) popular view (PV). Western Scientific Views relate to methods of discovery and organization of knowledge gained through experience and empirical knowledge. Supernatural views are those responses relating to that which is above or beyond nature. Popular views are those held by majority of people which may in actual sense lack empirical or supernatural explanations. The instrument was designed to explore students' alternative conceptions of scientific phenomena with particular reference to "motion". 500 questionnaires were filled and returned. Data generated were analysed item by item using frequency, percentage and chi square. A value obtained for each item in the questionnaire using age as the classification variable. The score of each candidate in each dimension was determined by number of items in which reflected views along that dimension. A frequency and percentage sure for each view was determined. Summarily, the research questions were answer using frequencies and percentages while the hypotheses were tested using cross tabulation with chi-square test of independence as the test statistic. 


\section{Results}

\section{Research question 1:}

What are the alternative conceptions of students on motion.

Data as regards the conception of students on motion are presented in Table 1

\section{Table 1:}

Students' Alternative Conception on Motion

\begin{tabular}{|c|c|c|c|c|c|c|c|c|c|c|c|}
\hline \multirow{2}{*}{ Item } & \multirow{2}{*}{$\begin{array}{l}\text { Questions describing } \\
\text { issues/phenomena }\end{array}$} & \multicolumn{2}{|c|}{ WS* } & \multicolumn{2}{|c|}{$\mathrm{SN}^{* *}$} & \multicolumn{2}{|c|}{$\mathbf{P} * * *$} & \multicolumn{2}{|c|}{ Null $* * * *$} & \multicolumn{2}{|c|}{ Total } \\
\hline & & No & $\%$ & No & $\%$ & No & $\%$ & No & $\%$ & No & $\%$ \\
\hline & $\begin{array}{l}\text { Motion of aeroplane from } \\
\text { Enugu to Lagos }\end{array}$ & 285 & 57.0 & 39 & 7.8 & 134 & 30.8 & 22 & 4.4 & 500 & 100 \\
\hline 2 & $\begin{array}{l}\text { Cause of motion of an } \\
\text { object }\end{array}$ & 420 & 84.0 & 28 & 5.6 & 29 & 5.8 & 23 & 4.6 & 500 & 100 \\
\hline 3 & $\begin{array}{l}\text { Exhibition of a projectile } \\
\text { motion from a bullet }\end{array}$ & 335 & 67.0 & 28 & 5.0 & 108 & 21.6 & 29 & 5.8 & 500 & 100 \\
\hline 4 & $\begin{array}{l}\text { Earth revolving round the } \\
\text { sum }\end{array}$ & 323 & 64.6 & 25 & 5.0 & 95 & 19.0 & 57 & 11.4 & 500 & 100 \\
\hline 5 & $\begin{array}{l}\text { Opposition of motion } \\
\text { between two surfaces }\end{array}$ & 89 & 17.8 & 112 & 22.4 & 5 & 1.0 & 294 & 588 & 500 & 100 \\
\hline
\end{tabular}




\begin{tabular}{|c|c|c|c|c|c|c|c|c|c|c|c|}
\hline 6 & $\begin{array}{l}\text { Explanation to climbing of } \\
\text { a staircase being tiresome }\end{array}$ & 2.22 & 44.4 & 54 & 10.8 & 82 & 16.4 & 142 & 28.4 & 500 & 100 \\
\hline 7 & $\begin{array}{l}\text { Student on projectile } \\
\text { motion }\end{array}$ & 122 & 24.4 & 26 & 5.2 & 280 & 56.0 & 72 & 14.4 & 500 & 100 \\
\hline 8 & $\begin{array}{l}\text { Reason for heavier object } \\
\text { reaching the ground } \\
\text { before light one }\end{array}$ & 174 & 34.86 & 36 & 7.2 & 233 & 46.6 & 57 & 11.4 & 500 & 100 \\
\hline 9 & $\begin{array}{l}\text { Type of motion exhibited } \\
\text { by the planets moving } \\
\text { round the sum }\end{array}$ & 102 & 204 & 15 & 3.0 & 314 & 62.8 & 69 & 13.8 & 500 & 100 \\
\hline 10 & $\begin{array}{l}\text { Type of motion } \\
\text { experienced by a stone } \\
\text { fastened to a threat and } \\
\text { moved in a circle }\end{array}$ & 269 & 53.8 & 53 & 10.8 & 83 & 16.6 & 95 & 19.0 & 500 & 100 \\
\hline & Percentage average & & 47.0 & & 8.0 & & 28.0 & & 17.0 & & \\
\hline
\end{tabular}

$* * * * \mathbf{N}=\mathbf{N i l}$

The results from table 1 indicate that generally $47 \%$ of students had western scientific view while $8 \%$ had supernatural view, $28 \%$ had popular view and $17 \%$ of the students had nil view.

Observing the table further shows that students indicate that items 2, 3, 4, 10 have Western Scientific views with percentage frequency scores of 84.0, 67.0, 64.6 and 53.8 respectively while items with supernatural view had very low percentage frequency scores ranging from $22.4 \%$ for item 4 to $50 \%$ for item 7 . On the popular view, items 9 , 7 and 8 had their highest frequency counts with $62.8 \%, 5.6 \%$ and $46.6 \%$ frequency scores respectively.

However some students did not indicate any view in some of the items. For instance, item 5 had the highest nil view with $58.8 \%$ frequency count followed by item 6 with frequency score of $28.4 \%$ and item 1 had lowest nil view with only $4 \%$ frequency count. 
Research Question 2

To what extent does age influence the alternative conception of students on motion?

Table 2:

Age related difference on students' perception of motion

\begin{tabular}{|c|c|c|c|c|c|c|c|c|c|c|c|c|c|}
\hline \multirow{2}{*}{$\begin{array}{c}\text { Ite } \\
\text { m }\end{array}$} & \multirow{2}{*}{$\begin{array}{c}\text { Question } \\
\text { describin } \\
\text { g } \\
\text { Phenome } \\
\text { na }\end{array}$} & \multicolumn{4}{|c|}{$9-12$ years } & \multicolumn{4}{|c|}{$12^{+}-15$ years } & \multicolumn{4}{|c|}{$15^{+}-$and above } \\
\hline & & WS & $\mathbf{S N}$ & $\mathbf{P}$ & NIL & WS & SN & $\mathbf{P}$ & NIL & WS & SN & $\mathbf{P}$ & NIL \\
\hline 1 & $\begin{array}{c}\text { Motion } \\
\text { of } \\
\text { aeroplane } \\
\text { from } \\
\text { Enugu to } \\
\text { Lagos }\end{array}$ & $\begin{array}{c}5 \\
\\
(62 . \\
5)\end{array}$ & $\begin{array}{c}1 \\
\\
(12 . \\
5)\end{array}$ & $\begin{array}{c}2 \\
\\
(25 . \\
0)\end{array}$ & $\begin{array}{c}0 \\
(0.0)\end{array}$ & $\begin{array}{c}98 \\
\\
(75.4 \\
\quad)\end{array}$ & $\begin{array}{c}6 \\
(4.6)\end{array}$ & $\begin{array}{c}22 \\
\\
(16 . \\
9)\end{array}$ & $\begin{array}{c}4 \\
(3.1)\end{array}$ & $\begin{array}{c}182 \\
(50 . \\
3)\end{array}$ & $\begin{array}{c}32 \\
(8.8)\end{array}$ & $\begin{array}{c}130 \\
(55 . \\
9)\end{array}$ & $\begin{array}{c}18 \\
(5.0)\end{array}$ \\
\hline 2 & $\begin{array}{l}\text { Cause of } \\
\text { Motion of }\end{array}$ & $\begin{array}{c}8 \\
\\
(10 . \\
0)\end{array}$ & $\begin{array}{c}0 \\
(0.0)\end{array}$ & $\begin{array}{c}0 \\
(0.0)\end{array}$ & $\begin{array}{c}0 \\
(0.0)\end{array}$ & $\begin{array}{c}111 \\
\\
(85.4 \\
)\end{array}$ & $\begin{array}{c}6 \\
(4.6)\end{array}$ & $\begin{array}{c}5 \\
(3.8)\end{array}$ & $\begin{array}{c}8 \\
(6.2)\end{array}$ & $\begin{array}{l}301 \\
83.1\end{array}$ & $\begin{array}{c}22 \\
(6.1)\end{array}$ & $\begin{array}{c}210 \\
(58 . \\
0)\end{array}$ & $\begin{array}{r}54 \\
(4.1)\end{array}$ \\
\hline 3 & $\begin{array}{c}\text { Exhibitio } \\
\mathrm{n} \text { of a } \\
\text { projectile } \\
\text { motion } \\
\text { from a }\end{array}$ & $\begin{array}{c}7 \\
(8.5)\end{array}$ & $\begin{array}{c}0 \\
(0.0)\end{array}$ & $\begin{array}{c}1 \\
\\
(12 . \\
5)\end{array}$ & $\begin{array}{c}0 \\
(0.0)\end{array}$ & $\begin{array}{c}79 \\
\\
(60.8 \\
\quad)\end{array}$ & $\begin{array}{c}8 \\
(6.2)\end{array}$ & $\begin{array}{c}26 \\
(20 . \\
0)\end{array}$ & $\begin{array}{c}17 \\
\\
(13 . \\
1)\end{array}$ & $\begin{array}{c}249 \\
(50 . \\
3)\end{array}$ & $\begin{array}{c}20 \\
(8.8)\end{array}$ & $\begin{array}{c}81 \\
(35 . \\
9)\end{array}$ & $\begin{array}{r}12 \\
(5.0)\end{array}$ \\
\hline
\end{tabular}




\begin{tabular}{|c|c|c|c|c|c|c|c|c|c|c|c|c|c|}
\hline & bullet & & & & & & & & & & & & \\
\hline 4 & $\begin{array}{l}\text { Earth } \\
\text { revolving } \\
\text { round the } \\
\text { sun }\end{array}$ & $\begin{array}{c}6 \\
(75 . \\
5)\end{array}$ & $\begin{array}{c}1 \\
\\
(12 . \\
5)\end{array}$ & $\begin{array}{c}0 \\
(0.0)\end{array}$ & $\begin{array}{r}1 \\
\\
(12 . \\
1)\end{array}$ & $\begin{array}{c}80 \\
\\
(61.5 \\
)\end{array}$ & $\begin{array}{c}6 \\
(4.6)\end{array}$ & $\begin{array}{c}24 \\
\\
(18 . \\
5)\end{array}$ & $\begin{array}{c}20 \\
\\
(15 . \\
4)\end{array}$ & $\begin{array}{c}237 \\
\\
(65 . \\
5)\end{array}$ & $\begin{array}{c}18 \\
(5.0)\end{array}$ & $\begin{array}{c}71 \\
\\
(19 . \\
6)\end{array}$ & $\begin{array}{r}36 \\
(9.6)\end{array}$ \\
\hline 5 & $\begin{array}{c}\text { Oppositio } \\
\text { n of } \\
\text { motion } \\
\text { between } \\
\text { two } \\
\text { surfaces }\end{array}$ & $\begin{array}{l}2 \\
(25 . \\
0)\end{array}$ & $\begin{array}{c}3 \\
\\
(37 . \\
5)\end{array}$ & $\begin{array}{c}0 \\
(0.0)\end{array}$ & $\begin{array}{r}3 \\
\\
(37 . \\
5)\end{array}$ & $\begin{array}{c}34 \\
(26.2 \\
)\end{array}$ & $\begin{array}{c}23 \\
\\
(17 . \\
7)\end{array}$ & $\begin{array}{c}1 \\
(0.8)\end{array}$ & $\begin{array}{l}72 \\
\\
(55 . \\
4)\end{array}$ & $\begin{array}{c}53 \\
\\
(14 . \\
6)\end{array}$ & $\begin{array}{c}86 \\
\\
(23 . \\
8)\end{array}$ & $\begin{array}{c}4 \\
(1.1)\end{array}$ & $\begin{array}{c}219 \\
(60 . \\
9)\end{array}$ \\
\hline 6 & $\begin{array}{l}\text { Explanati } \\
\text { on to } \\
\text { climbing } \\
\text { of a } \\
\text { staircase } \\
\text { being }\end{array}$ & $\begin{array}{c}6 \\
\\
(75 . \\
0)\end{array}$ & $\begin{array}{c}1 \\
\\
(12 . \\
5)\end{array}$ & $\begin{array}{c}1 \\
\\
(12 . \\
5)\end{array}$ & $(0.0$ & $\begin{array}{c}60 \\
(43.1 \\
)\end{array}$ & $\begin{array}{c}13 \\
(3.8)\end{array}$ & $\begin{array}{c}18 \\
\\
(42 . \\
6)\end{array}$ & $\begin{array}{c}39 \\
\\
(28 . \\
5)\end{array}$ & $\begin{array}{l}156 \\
(43 . \\
1)\end{array}$ & $\begin{array}{c}40 \\
(3.3)\end{array}$ & $\begin{array}{c}63 \\
\\
(22 . \\
7)\end{array}$ & $\begin{array}{c}103 \\
(30 . \\
9)\end{array}$ \\
\hline 7 & $\begin{array}{l}\text { Statement } \\
\text { on } \\
\text { projectile } \\
\text { motion }\end{array}$ & $\begin{array}{c}1 \\
(12 . \\
5)\end{array}$ & $\begin{array}{c}1 \\
\\
(12 . \\
5)\end{array}$ & $\begin{array}{c}4 \\
\\
(50 . \\
0)\end{array}$ & $\begin{array}{r}(25 \\
0)\end{array}$ & $\begin{array}{c}41 \\
(31.5 \\
)\end{array}$ & (5.4) & $\begin{array}{c}66 \\
\\
(50 . \\
8)\end{array}$ & $\begin{array}{c}16 \\
\\
(12 . \\
3)\end{array}$ & $\begin{array}{c}80 \\
\\
(22 . \\
1)\end{array}$ & $\begin{array}{c}18 \\
(5.0)\end{array}$ & $\begin{array}{r}210 \\
58.0\end{array}$ & $\begin{array}{c}54 \\
\\
(14 . \\
9)\end{array}$ \\
\hline 8 & $\begin{array}{l}\text { Reason } \\
\text { for }\end{array}$ & $\begin{array}{c}5 \\
\\
(62 . \\
5)\end{array}$ & $\begin{array}{c}1 \\
\\
\text { (12. } \\
5)\end{array}$ & $\begin{array}{c}2 \\
(25 . \\
0)\end{array}$ & $(0.0$ & $\begin{array}{c}48 \\
(36.9 \\
)\end{array}$ & (6.2) & $\begin{array}{r}57 \\
\\
(43 . \\
8)\end{array}$ & 13.1 & $\begin{array}{r}121 \\
33.4\end{array}$ & $\begin{array}{c}27 \\
(7.5)\end{array}$ & $\begin{array}{l}174 \\
\\
(48 . \\
1)\end{array}$ & $\begin{array}{c}40 \\
(11 . \\
0)\end{array}$ \\
\hline & $\begin{array}{l}\text { Object } \\
\text { reaching }\end{array}$ & & & & & & & & & & & & \\
\hline
\end{tabular}




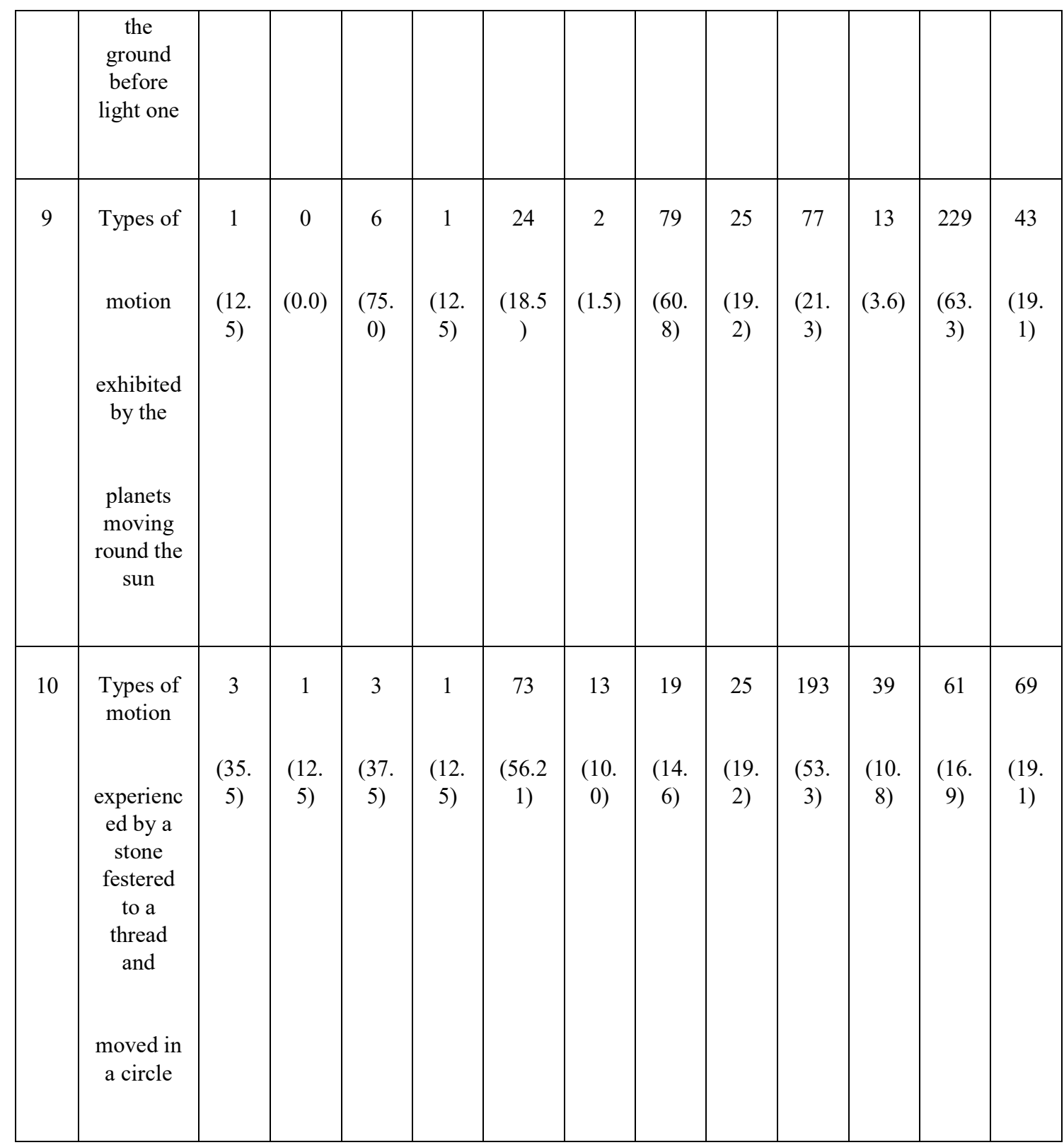

\footnotetext{
No of students for $9-12$ years $=$

$\begin{array}{lll}\text { WS } & =\text { Western Scientific } \\ \mathrm{P} & = & \text { Popular }\end{array}$
}

8

No of students for $12^{+}-15$ years $=\quad 130$

No of students for $15^{+}$and above $=362$ 
$\mathrm{N} \quad=\quad$ No Answer

Values in bracket are percentages.

The result from table 2 shows that generally majority of highest percentage of students in different age groups are of western scientific view in most of the items. However some lesser percentage of students in different age groups had supernatural, popular and nil views of the concepts. Students in the age bracket $9-12$ years that have western scientific view range from $75 \%$ for items 4 and 6 to $12.5 \%$ for items 7 and 9 . Moreover students in the age bracket of $9-12$ years that have supernatural view range from $37.5 \%$ to $0 \%$ for item 5 to items 2,3 , and 9 respectively. Also students for popular view within same age bracket of $9-12$ years from $75 \%$ to $0 \%$ for items 9 to items 2,4 , and 5 respectively. Also for nil view within same range age bracket of $9-12$ years range from $37.5 \%$ to $0 \%$ for item 5 to items $1,2,3,6$ and 8 respectively.

Furthermore students in the age bracket of $12^{+}-15$ years that have western scientific range from $85.4 \%$ to $18.5 \%$ for item 2 to item 9 . While students in the same age group of $12^{+}-15$ years that have supernatural view range from $17.7 \%$ to $1.5 \%$ for item 5 to item 9 respectively. Moreover students within the age bracket of $2^{+}-15$ years that have popular view range from $60.8 \%$ to $0.8 \%$ for item 9 to item 5 respectively. Also students within this same age bracket that have nil view range from $55.4 \%$ to $3.1 \%$ for item 5 and item 1 respectively.

In addition students in the age bracket of $15^{+}$and above that have western scientific view range from $83.1 \%$ to $21.3 \%$ for item 4 to item 12 . Moreover students within the age bracket of 15 and above have supernatural view range from $23.8 \%$ to $3.3 \%$ for item 5 to item 6 respectively. While students within this same age bracket that have popular view range from $63.3 \%$ to $1.1 \%$ for item 9 to item 5 and also students in the age bracket of $15^{+}$and above that have nil view range from $60.9 \%$ to $4.1 \%$ for item 5 to item 2 respectively.

\section{Hypothesis}

HO: Senior Secondary School Students' alternative conceptions of motion are significantly $(\mathrm{P}<0.05)$ independent of age.

The result of the test of hypothesis one is presented in table 3 
Table 3:

$X^{2}$ of Age Difference in students' conception of motion

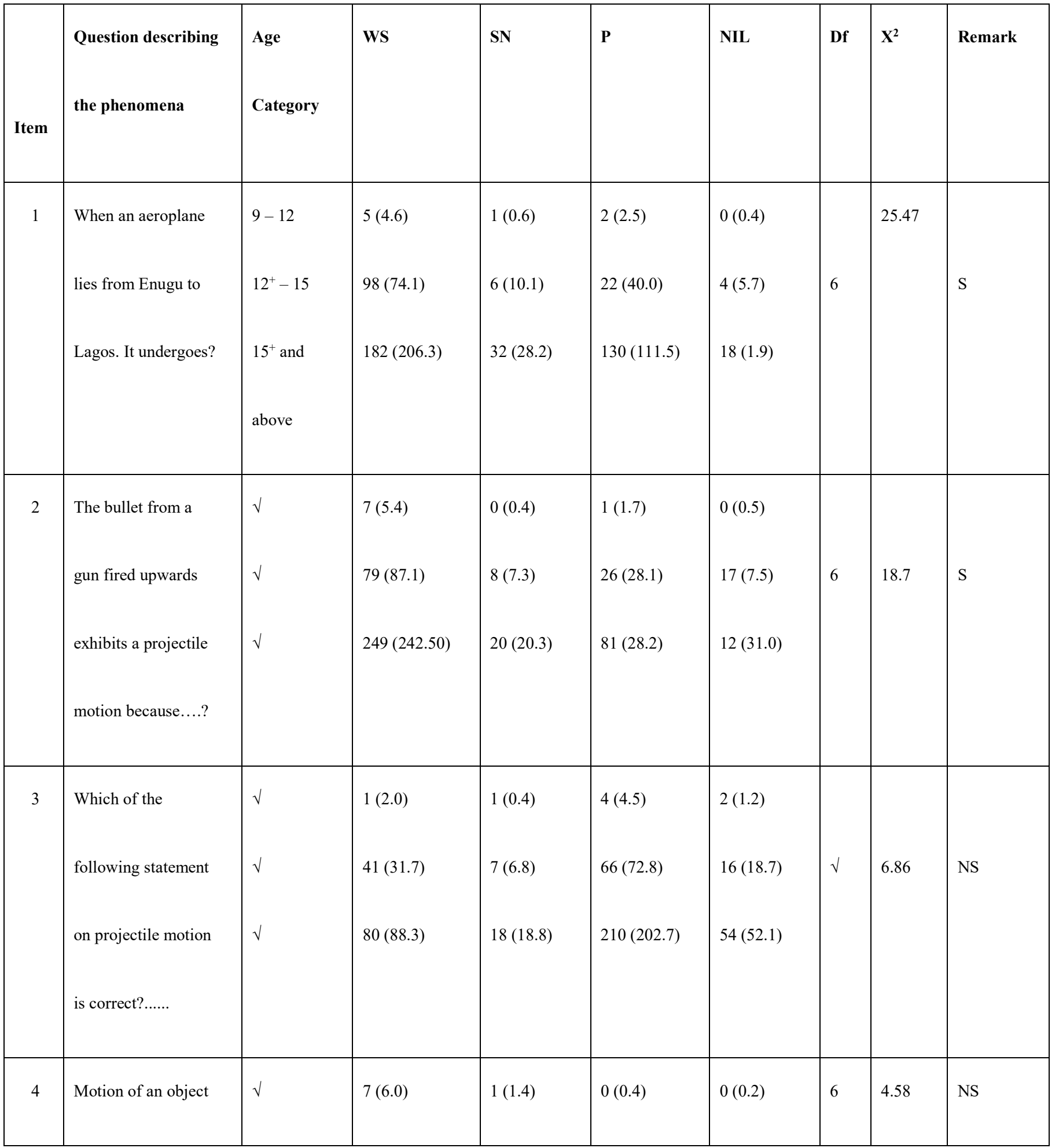




\begin{tabular}{|c|c|c|c|c|c|c|c|c|c|}
\hline & is caused by?............. & $\sqrt{ }$ & $\begin{array}{l}104(94.5) \\
264(271.5)\end{array}$ & $\begin{array}{l}16(22.1) \\
68(61.5)\end{array}$ & $\begin{array}{l}6(7.3) \\
22(20.3)\end{array}$ & $\begin{array}{l}4(3.1) \\
8(8.7)\end{array}$ & & & \\
\hline 5 & $\begin{array}{l}\text { What type of force } \\
\text { keeps the earth } \\
\text { revolving round the } \\
\text { sun? ......... }\end{array}$ & $\begin{array}{l}\sqrt{ } \\
\sqrt{ }\end{array}$ & $\begin{array}{l}6(5.2) \\
80(84.0) \\
237(233.9)\end{array}$ & $\begin{array}{l}1(0.4) \\
6(6.5) \\
18(18.1)\end{array}$ & $\begin{array}{l}0(1.5) \\
24(24.7) \\
71(68.8)\end{array}$ & $\begin{array}{l}1(0.9) \\
20(14.8) \\
36(41.3)\end{array}$ & $\sqrt{ }$ & 5.41 & NS \\
\hline 6 & $\begin{array}{l}\text { What type of force } \\
\text { helps a man to walk } \\
\text {........? }\end{array}$ & $\begin{array}{l}\sqrt{ } \\
\sqrt{ }\end{array}$ & $\begin{array}{l}7(6.0) \\
104(97.5) \\
264(271.5)\end{array}$ & $\begin{array}{l}1(1.4) \\
16(22.1) \\
68(61.5)\end{array}$ & $\begin{array}{l}0(0.4) \\
6(7.3) \\
22(20.3)\end{array}$ & $\begin{array}{l}0(0.2) \\
4(3.1) \\
8(8.7)\end{array}$ & 6 & 4.58 & NS \\
\hline 7 & $\begin{array}{l}\text { Man to walk } \\
\text { without falling }\end{array}$ & $\begin{array}{l}\sqrt{ } \\
\sqrt{ }\end{array}$ & $\begin{array}{l}264(271.5) \\
104(97.5) \\
7(6.0)\end{array}$ & $\begin{array}{l}68(61.5) \\
16(22.1) \\
1(1.4)\end{array}$ & $\begin{array}{l}22(20.3) \\
6(7.3) \\
0(0.4)\end{array}$ & $\begin{array}{l}8(8.7) \\
4(3.1) \\
0(0.2)\end{array}$ & $\sqrt{ }$ & 4.58 & NS \\
\hline 8 & $\begin{array}{l}\text { A child playing with } \\
\text { a piece of metal } \\
\text { found that the piece } \\
\text { of metal is attracting a } \\
\text { razor blade. This } \\
\text { indicates that .....? }\end{array}$ & $\sqrt{ }$ & $\begin{array}{l}7(5.5) \\
88(88.7) \\
246(246.9)\end{array}$ & $\begin{array}{l}0(0.5) \\
10(8.8) \\
24(24.6)\end{array}$ & $\begin{array}{l}1(1.3) \\
20(21.6) \\
62(60.1)\end{array}$ & $\begin{array}{l}0(0.7) \\
12(10.9) \\
30(30.4)\end{array}$ & $\sqrt{ }$ & 2.20 & NS \\
\hline 9 & When a man slaps & $\sqrt{ }$ & $7(5.5)$ & $1(0.7)$ & $0(0.9)$ & $0(0.9)$ & & & \\
\hline
\end{tabular}




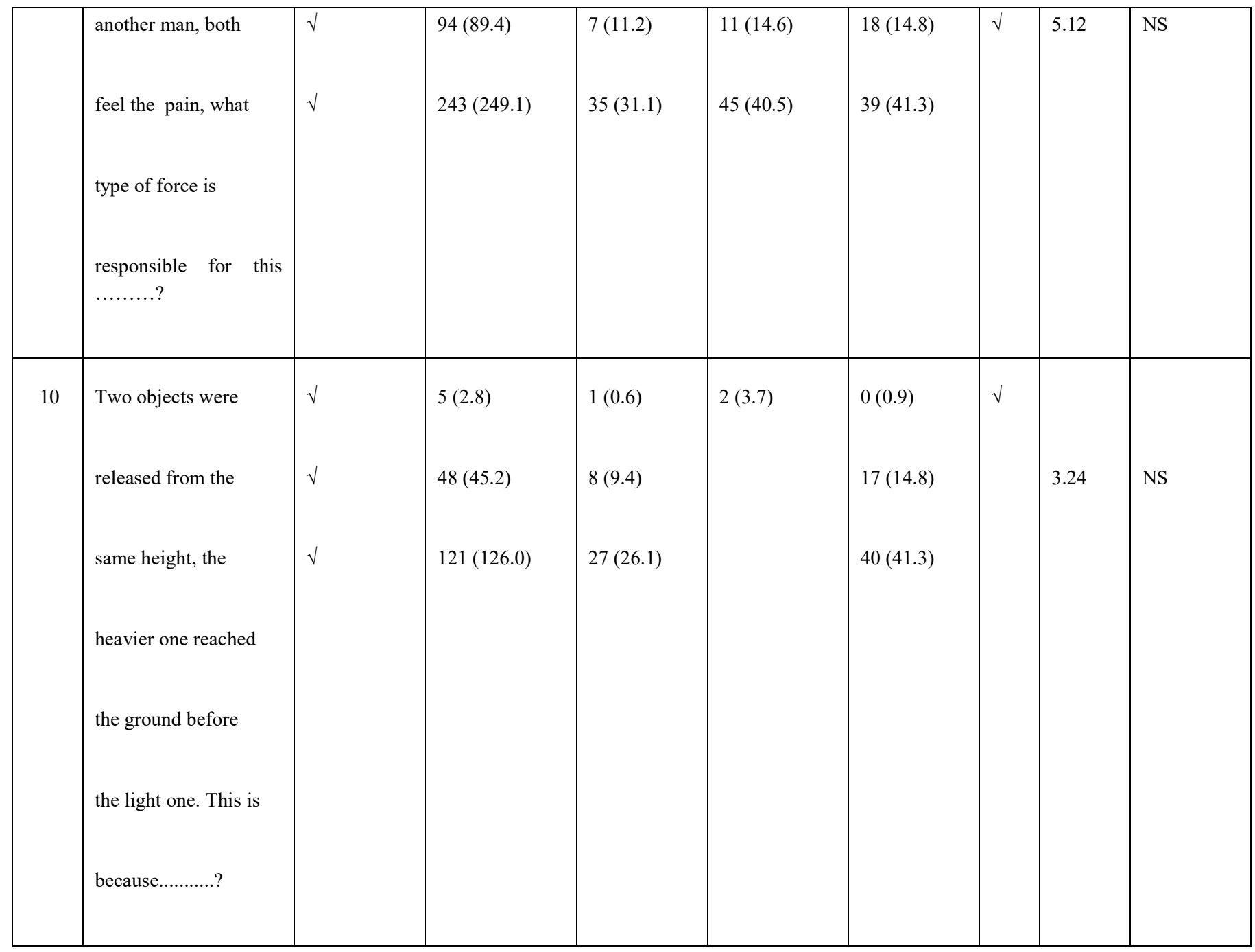

NOTE:

Values in bracket are expected frequencies

$\mathrm{X}^{2}$ tabular $(\mathrm{P} \leq 0.05)=12.59$

From table $63, \mathrm{X}^{2}$ calculated are less than $\mathrm{X}^{2}$ tabular at 0.05 level of probability in all the questions raised except questions 1 and 2 .

As a result, this null hypothesis that students' alternative conceptions of motion are significantly independent of age is accepted for questions 3 to 10 and rejected for questions 1 and 2 . 


\section{Summary of the Findings}

1. Out of 500 subjects who answered the questionnaire, $47 \%$ of the subjects had the western scientific view, $8 \%$ had the supernatural view (SN), $28 \%$ had popular view while $17 \%$ of the subject had no view. This shows that most of students had western scientific view.

2. $75 \%$ of the students within the age range of $9-12$ years had western scientific view in 2 concepts, $12.5 \%$ of the students had western scientific view in 2 concepts in the age range of $9-12$ years, $37.5 \%$ of the students had supernatural view in one concept and $37.5 \%$ of students within this range did not answer any question. Also $75 \%$ of the students had popular view in one concept.

3. Among those in the range of $12^{+}-15$ years $85.4 \%$ of the students had western scientific in one concept, those with supernatural view is $17.7 \%$ in one concept and those with popular view is $60.8 \%$ in one concept. Also among those within the range of $15^{+}$and above, those with scientific view $(83.1 \%)$ is highest in one concept, those with supernatural $(23.8 \%)$ is highest in one concept and those with popular view $(63.3 \%)$ is highest in one concept.

\section{Discussion}

The data collected with respect to Alternative Conception of Scientific Phenomena Test (ACSPT) were analyzed quantitatively in terms of western scientific view, supernatural view and popular view. Table 1 reveals that about $84.0 \%$ of respondents had western scientific view over cause of motion, $5.6 \%$ of students were of the opinion that motion is caused by energy from Supreme Being while $5.8 \%$ of students have the view that pressure on the environment causes motion. This group of respondents had alternative conception about the cause of motion which was not western scientific view but popular. About $85.0 \%$ of the respondents were of the view that the spiritual force guiding the man helps him to walk without falling. This is regarded as the supernatural view. Also about $62.8 \%$ of students had the belief that planet moving round the sun exhibits rotational motion.

Table 1 also reveals that more than $65 \%$ of the respondents had western scientific view of relative velocity with respect to objects. They also have reason for projectile, the type of force that keeps the earth revolving round magnetic property of attracting objects. In the above circumstances, some of the respondents however had supernatural view of projectile motion.

On the reason why a heavier object reached the ground before the lighter one, about $34.7 \%$ of the respondents were able to indicate the effect of air resistance on the light object while up to half of the respondents still held to their popular view and supernatural view probably either rag a result of wrong conception as regards parents; their views were either that the end of air was angry with the higher objects or that the heavier one had more speed than the lighter one.

Fafunwa (1983) observed that the non interpretation of African culture into the leaving process tend to distort the cognitive process in terms of anticipated outcome in western science. This is because indigenous concepts are culturally based and supernaturally re-enforced. Nelson (1974) in his analysis of concept is of the view that an African child acquires his concepts from the African environment. The findings of the study showed that most of the respondents that ticked western scientific views could not explain or reason scientifically but rather they reasoned culturally or supernaturally indicating rote-learning.

In the case of influence of age on alternative conception of students on motion. The findings revealed that students of 15 years and below had high percentage of western scientific view in most items than students of 15 years and above which is at variance with the study of Eckstein and Shemesh (1992) that the transformations of ideas increase with age. 
However, for the hypothesis, summary of table 3 indicates that the $\mathrm{X}^{2}$ calculated for eight concepts out of ten concepts was less than the $\mathrm{X}^{2}$ tabular of 12.59 at 0.05 level of significance. The null hypothesis for each of the alternative conceptions was accepted. This shows that age is not a significant factor in the senior secondary school student's alternative conceptions of motion on those concepts. On the other, the $\mathrm{X}^{2}$ calculated for concepts 1 and 2 was greater than the $X^{2}$ tabular of 12.59 . The decision rule is also to reject the null hypothesis whenever the calculated value is more than the critical value. The null hypothesis was rejected for the two concepts which implies that there was significant difference between students' age and alternative conceptions for those concepts.

\section{Conclusion}

Based on the findings of the study on the influence of age on students' alternative conceptions of scientific phenomena with particular reference to motion, the following conclusions were made.

1. Most senior secondary students hold western scientific view of motion.

2. Age may or may not be an important factor influencing school student to hold alternative conceptions about motion.

3. The tendency for senior secondary school students to hold alternative conceptions about motion and its inherent characteristics is determined by the interaction of personality, reasoning pattern and environment. Also their reasons for inherent characteristic of motion were central on their spiritual real.

\section{Recommendations}

1. Alternative scientific conceptions based science instruction should be adopted in our school system.

2. Ministry of Education and Professional Organizations like STAN should organize workshops, seminars and conferences for Physics teachers on the use of the scientific alternative conception based package.

3. The use of conventional instructional approach should be de - emphasized in our school system since it encourages rote-learning. Physics teachers should employ the principles of the alternative conception of science to enhance knowledge acquisition among students.

\section{References}

Bruner, J. (1996). Actual Minds Possible worlds. Cambridge M.A.: Harvard University Press.

Bruner, J. (2010). Actual Minds Possible worlds. Cambridge M.A.: Harvard University Press.

Cosgrove, M. \& Osborne, R. (2005). Teaching Sequence on Electric Current.nR. Osborne and P. Freyberg (ed.) Learning in Science. The

implication of children's science (112-123) Auckland: Heinemann.

Duckworth, E. (2010). The having of wonderful ideas and other Essay on Teaching and Learning. New work: Teachers College Press. 
Eckstein, S.G. \&Shemesh, M. (1989). Development of children's ideas on motion: Intuition vs Logical thinking. International Journal of

Science Education, 11, 327-336.

Eckstein, S.G. and Shemesh, M. (1992). In press Mathematical Modele of Cognitive Development. British Journal of Mathematical and Statistical Psychology,Pp 441-451.

Exline, J. (2000). Science, Technology and Society. Science Professional Development. [Online] Available: http://www.eduplace.com/science/profdev/articles/exline.html (March 26, 2019)

Eze, C.B. (2014). Evaluating Alternative Conceptions held by Senior Secondary School Students in Biology. Unpublished M.Ed. Thesis University of Nigeria, Nsukka.

Fafunwa, A.B. (1983). Wanted: Science and Technology in Mother tongue. A key address. 24 $4^{\text {th }}$ Annual Conference proceedings of STAN. 15-20.

Kharis, E. (2016). Influence of Misconceptions and Alternative Conceptions on Senior Senior Secondary School Students in Physics M.Ed. [Online] Research. Available: https://www.academia.edu/38149438/Influence of Misconceptions and Alternative Conceptions on Physics Students Kharis 2016.pdf (March 26, 2019).

Okafor, F.C. (2008). Philosophy of Education, 70, $105-109$.

Sadler, P.M. (2007). Psychometric Models of Student Conceptions in Science. Journal of Research in Science Teaching, 35, $265-275$.

Shayer, M and Wylam, H. (1981). The development of the concepts of neat and temperature in 10-30 years old. Journal of Research in

Science Teaching, 18, 419-434.

Acknowledgment

The researcher hereby acknowledges the following:

Her University Vice Chancellor, Prof. Greg. Nwakoby and Rev. Sr. Prof. B. A. Ezeliora for their moral encouragement; her husband Mr. S.C. Okafor for his financial and moral support; her children for their co-operation; and finally Chinenye Okwesilieze for doing the computer works. 